\title{
NRBP1 wt Allele
}

National Cancer Institute

\section{Source}

National Cancer Institute. NRBP1 wt Allele. NCI Thesaurus. Code C54370.

Human NRBP1 wild-type allele is located in the vicinity of 2 p23 and is approximately $14 \mathrm{~kb}$ in length. This allele, which encodes nuclear receptor-binding protein, may play a role in the mediation of protein trafficking. 